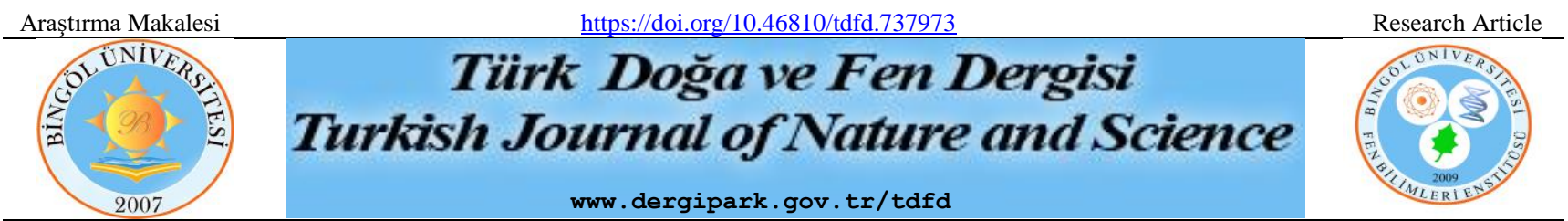

\title{
Merkapto-Fonksiyonlu Kaliks[4]aren Bazlı Polimer İçerikli Membranın Ağır Metal Taşıma Verimliliği
}

\author{
Mehmet Soner ENGIN ${ }^{1 *}$, Serkan SAYIN², Seydahmet CAY ${ }^{2}$ \\ ${ }^{1}$ Department of Food Engineering, Faculty of Engineering, Giresun University, 28200 Güre, Giresun, Turkey.
}

${ }^{2}$ Department of Environmental Engineering, Faculty of Engineering, Giresun

Mehmet Soner ENGIN: ORCID NO 0000-0001-5954-5628

Serkan SAYIN: ORCID NO 0000-0003-0518-3208

Seydahmet CAY: ORCID NO 0000-0003-0045-8217

*Sorumlu yazar: soner.engin@giresun.edu.tr

(Alınış: 15.05.2020, Kabul: 01.04.2021, Online Yayınlanma: 25.06.2021)

\begin{abstract}
Anahtar
Kelimeler

Kaliksaren,

İyon taşınımı,

A ğır metaller,

Polimer

içerikli

membran
\end{abstract}

\begin{abstract}
Öz: Bu çalışmada, bazı ağır metallerin, yeni bir membran (HS-C@PIM) kullanılarak sulu ortamdan verimli bir şekilde taşınması tasarlanmıştır. Bu amaçla; ağır metaller için uygun bir bağlanma yeri olan bir merkapto-sübstitüe kaliksaren türevi polimer içeren membranda taşıyıcı olarak kullanıldı. HS-C@PIM'in yapısını ve yüzey morfolojisini değerlendirmek için taramalı elektron mikroskopisi (SEM), Termogravimetrik analiz (TGA) ve elementel analiz teknikleri kullanıldı. HS-C@PIM' nin Cu(II), Zn(II), Pb(II), Ni(II), Cd(II) ve Co(II) ye karşın katyon taşıma etkinliğini değerlendirmek için Donnan diyaliz yöntemi uygulanmıştır. Sonuçlar, sırasıyla \%48.6, $\% 43.63, \% 47.08, \% 53.31, \% 39.00$ and \%49.42 olarak hesaplanmıştır.
\end{abstract}

\section{Heavy Metal Transport Efficiency of Mercapto-Functionalized Calix[4]arene Based Polymer Inclusion Membrane}

Keywords

Calixarene,

Ion

transportation,

Heavy metals,

Polymer

inclusion

membrane

\begin{abstract}
In this study, an efficient transportation of some heavy metals from aqueous media by using a novel membrane (HS-C@PIM) is designed. To this end, a mercapto-substituted calixarene derivative having a conveninet binding sites for heavy metals was used as carrier in polymer inclusion membrane. Scanning electron microscopy (SEM), Thermogravimetric analysis (TGA) and elemental analysis techniques were used to assess the structure and surface morphology of HSC@PIM. Donnan dialysis method was carried out to evaluate the cation transport efficiency of HSC@PIM against $\mathrm{Cu}(\mathrm{II}), \mathrm{Zn}(\mathrm{II}), \mathrm{Pb}(\mathrm{II}), \mathrm{Ni}(\mathrm{II}), \mathrm{Cd}(\mathrm{II})$ and $\mathrm{Co}(\mathrm{II})$. The results were calculated as $48.64 \%, 43.63 \%, 47.08 \%, 53.31 \%, 39.00 \%$ and $49.42 \%$ respectively.
\end{abstract}

\section{INTRODUCTION}

The rapid development of industry is the primary source of heavy metal ions.In addition to increasing contamination of industrial wastewater, it contributes to anthropogenic sources and agricultural wastes. Its accumulation in humans causes kidney failure, nervous system damage and bone damage and other serious diseases [1]. So far, a number of effective methods have been reviewed for the removal of heavy metals such as ion exchange, chemical precipitation, electrodialysis, reverse osmosis, nanofiltration, ultrafiltration, flocculation, flotation, coagulation, etc [2].
Membrane separation is a very important process for water purification. The high performance polymer membranes cost-effective, energy-efficient and environmentally friend. Various types of membranes continue to be developed for treatment applications [3]. Polymer inclusion membranes (PIMs) have better stability compared with other types of liquid membranes including BLMs (bulk liquid membranes), ELMs (emulsion liquid membranes) and SLMs (supported liquid membranes) due to negligible loss of carrier reagent from the membrane. Therefore, PIMs are becoming of great interest for the transport and separation of chemical species [4-7].

The elemental chemical composition of PIM is of the high-molecular-weight base polymer (cellulose triacetate 
(CTA) or polyvinylchloride (PVC)), a plasticizer, and a carrier.In the literature, there are many chemicals used as carriers,oximes, [8] thiacrown ethers, [9] calixarenes, [10; 11] azo-compounds, [12] dithiocarbamates [20] and thiophosphorus species [13]. In this work, we have developed a novel polymer inclusion membrane embedded marcapto derivative of calixarene was fabricated to investigate its transport efficiency towards some heavy metals. For this aim, synthesis of a mercapto-substituted calix[4]arene containing dicarboxylic acid units (5) was performed according to the literature [14-18]. Next, the mercapto-substituted calix[4]arene containing dicarboxylic acid units (5) was used to prepare the embedded marcapto derivative of calixarene (HS-C@PIM) in the media of 2-nitrophenyl octyl ether (o-NPOE) and cellulose triacetate (CTA). TGA, SEM and elemental analysis techniques were used to elucidate the structure and surface morphology of $\mathrm{C}$ @ PIM. In addition, the capacity of HS-C@PIM to transport trace metals has been successfully investigated using a Donnan dialysis system.

\section{EXPERIMENTAL}

\subsection{Chemicals and Materials}

N,N-dimethylformamide

(DMF), dichloromethane (DCM), hydrochloric acid ( $\mathrm{HCl})$, lead(II) nitrate (( $\mathrm{Pb}(\mathrm{NO} 3) 2)$ cadmium(II) nitrate tetrahydrate $((\mathrm{Cd}(\mathrm{NO} 3) 2 \bullet 4 \mathrm{H} 2 \mathrm{O}),$,$\quad Copper sulphatepentahydrate$ (CuSO4.5H2O) and cobalt sulphatehexahydrate (CoSO4.7H2O), were purchased from Merck.Nickel(II) sulfates (NiSO4) and Zinc(II) nitrate (ZnNO3), cellulose triacetate (CTA-678.6 g/mol), 2-nitrophenyl octyl ether (o-NPOE)waspurchasedfromSigma-Aldrich. TLC silica gel plates (SiO2, Merck PF254) were performed for thin layer chromatography studies.The Gallenkampinstrument was used for melting point determination.Bruker $400 \mathrm{MHz}$ spectrometer was used for NMR spectra.All solutions were prepared from a Milli-Q (Millipore Corp.) using ultrapure water.

\subsection{Synthesis}

Literature procedures was applied to synthesize p-tertbutylcalix[4]arene (1), 5,11,17,23-tetra-tert-butyl-25,27bis-(bromopropoxy)-26,28-dihydroxycalix[4]arene (2), 5,11,17,23-tetra-tert-butyl-25,27-bis(3-thiol-1oxypropane)-26,28-dihydroxycalix[4]arene (3), 5,17-bistert-butyl-11,23-dicarboxaldehyde-25,27-dihydroxy26,28-bis(3-thiol-1-oxypropane)calix[4]arene (4) and 5,17-bis-tert-butyl-11,23-dicarboxylic acid-25,27dihydroxy-26,28-bis(3-thiol-1-oxypropane)calix[4]arene (5) were synthesized by procedures published in the literature [14-18].

\subsubsection{5,17-Bis-tert-butyl-11,23-dicarboxaldehyde- 25,27-dihydroxy-26,28-bis(3-thiol-1-oxypropane)- calix[4]arene (4)}

Yield: 0.15 g (55.6\%), m.p.; 262-264 oC. 1H NMR (400 $\mathrm{MHz}, \mathrm{CDCl} 3): \delta 9.71(\mathrm{~s}, 2 \mathrm{H},-\mathrm{CHO}), 7.59$ (s, 4H, ArH), 7.14 (s, 4H, ArH), 4.22 (d, 4H, J =12.8 Hz, CH2), 4.06 $(\mathrm{t}, 4 \mathrm{H}, \mathrm{J}=4.8 \mathrm{~Hz}, \mathrm{O}-\mathrm{CH} 2), 3.53(\mathrm{~d}, 4 \mathrm{H}, \mathrm{J}=12.8 \mathrm{~Hz}$, CH2), 3.44-3.46 (m, 4H, CH2-S), 3.44-3.45 (m, 4H, CH2), 2.42-2.48 (m, 2H, -SH), 1.19 (s, 18H, (CH3)3C). 13C NMR (400 MHz, CDCl3): $\delta 190.79,159.40,148.95$, $148.81,132.61,130.97,129.15,128.68,126.53,75.16$, $34.43,33.82,32.10,31.29,28.22$. Anal. Calcd for C44H52O6S2:C, 71.32; H, 7.07; S, 8.65. Found (\%); C, $71.29 ; \mathrm{H}, 7.17 ; \mathrm{S}, 8.56$.

\subsubsection{5,17-Bis-tert-butyl-11,23-dicarboxylic acid- 25,27-dihydroxy-26,28-bis(3-thiol-1-oxypropane)- calix[4]arene (5)}

Yield: 0.015 g (43\%), m.p.; 160-162 oC. 1H NMR (400 MHz, DMSO): $\delta 7.82$ (s, 4H, ArH), 7.16 (s, 4H, ArH), 4.08-4.22 (m, 8H, CH2 and $\mathrm{O}-\mathrm{CH} 2), 3.48-3.68(\mathrm{~m}, 8 \mathrm{H}$, $\mathrm{CH} 2$ and $\mathrm{CH} 2-\mathrm{S}$ ), 2.27-2.47 (m, 4H, CH2), 1.99 (brs, $2 \mathrm{H},-\mathrm{SH}), 1.11$ (s, 18H, (CH3)3C). 13C NMR (400 MHz, DMSO): $\delta$ 167.66, 157.56, 149.95, 147.86, $132.77,130.81,128.45,126.51,121.98,76.20,34.54$, 34.11, 31.53, 31.38, 26.52. Anal.calcd for C44H52O8S2: C, 68.37; H, 6.78; S, 8.30. Found (\%); C, 68.31; H, 6.67; S, 8.48.

\subsection{Polymer inclusion membrane preparation}

Polymer inclusion membranes with calixarene additive were fabricated according to our previous study [19]. Support CTA $(0.2 \mathrm{~g})$ and ion carrier $(10 \mathrm{mg})$ were dissolved in dichloromethane $(20 \mathrm{~mL})$, and the mercapto-substituted calix[4]arene containing dicarboxylic acid units (5) (10 mg) were dissolved in dichloromethane $(20 \mathrm{~mL})$, and then a solution was prepared by adding plasticizer (o-NPPE, $0.3 \mathrm{~mL}$ ). Obtained mixture was poured onto a glass petri dish and then the volatile component was evaporated under room temperature. Finally, calixarene-based membrane was easily taken up after pouring pure water on glass petri dish (Zawierucha et al., 2013). The thickness of the calixarene-based membrane was determined with a digital micrometer (Mitutoyo). No significant flow was observed from the membrane in the control experiments.

\subsection{Characterization}

Thermogravimetric analysis, elemental analysis (TGA) and scanning electron microscope (SEM) techniques were performed to characterize HS-C@PIM.

\subsection{Transport Experiments}

Donnan dialysis method as the transport of heavy metal ions to an aqueous solution was carried out using a cell consisting of two detachable sections made of Teflon [3]. The Membrane, with a surface area of $7 \mathrm{~cm} 2$, is firmly clamped between two $40 \mathrm{~mL}$ chambers. Both chambers were mixed with a magnetic stirrer at $500 \mathrm{rpm}$ during the experiment. All measurements were carried out at $24^{\circ} \mathrm{C}$. While the receiving phase contains deionized water, the feed phase contains 10-5 mol / L heavy metal solutions complexed with picric acid.The solution $(1 \mathrm{~mL})$ was sampled at regular intervals (every 2 hours) and the amount of heavy metal ions passing 
through the membrane was measured with UV-VIS. (Hach Lange DR 6000 model).

The value of the starting flux (J0, mol m2-s1-) was used to evaluate the transition rate of HS-C@ PIMs in the PIM / solution interface, calculated using the equation below:

$$
\mathrm{J}_{0}=-\left(\frac{\mathrm{V}}{\mathrm{A}}\right)\left(\frac{\mathrm{dC}}{\mathrm{dt}}\right)_{\mathrm{t}=0}=-\left(\frac{\mathrm{V}}{\mathrm{A}}\right)\left(\frac{\mathrm{C}_{\mathrm{t}}-\mathrm{C}_{\mathrm{t}=0}}{\mathrm{t}}\right)
$$

where $\mathrm{A}=7.0 \times 103 \mathrm{~m} 2$, the feed solution is exposed to the membrane area, $\mathrm{V}=0.4 \times 105-\mathrm{m} 3$ is the feed solution volume, $\mathrm{Ct}=0$ and Ctare the initial and final metal concentrations in the feed solution (mol m3-), respectively, $\mathrm{t}=144 \mathrm{~h}$.

The recovery factors $(\% \mathrm{RF})$ of trace metals were calculated from the following equation:

$$
\% R F=\left(1-\frac{C_{r}}{C_{f}}\right) \cdot 100
$$

where $\mathrm{Cr}$ and $\mathrm{Cf}(\mathrm{mol} / \mathrm{L})$ were metal concentrations in the receiver and the feed phases, respectively.

\section{RESULT AND DISCUSSION}

\subsection{Synthesis and Characterization}

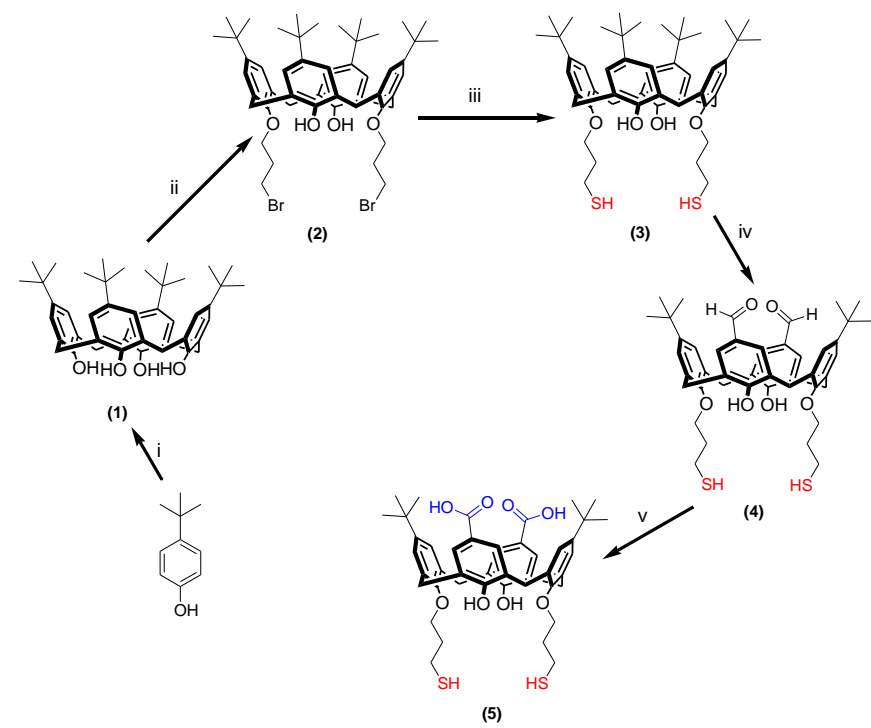

Scheme 1. Synthesis of the mercapto-substituted calix[4]arene containing dicarboxylic acid units (5). Reaction conditions: (i) HCHO; $\mathrm{NaOH}$; (ii) $\mathrm{K} 2 \mathrm{CO}$; ; 1,3-dibromopropane; (iii) thiourea, $\mathrm{KOH}$; (iii) TFA, hexamethylenetetramine; and (iv) sulfamic acid, sodium chlorite.

The carrier employed in the study is depicted in Scheme 1. In order to synthesis target calixarene derivative, convenient literature procedures were applied. Incorporated mercapto derivative of calixarene was then used as an additive in the media of cellulose triacetate (CTA) and o-NPOE to afford a new polymer inclusion membrane embedded calixarene(HS-C@PIM). A combination of TGA, SEM and elemental analysis techniques was used to assess the structure and surface morphology of HS-C@PIM.

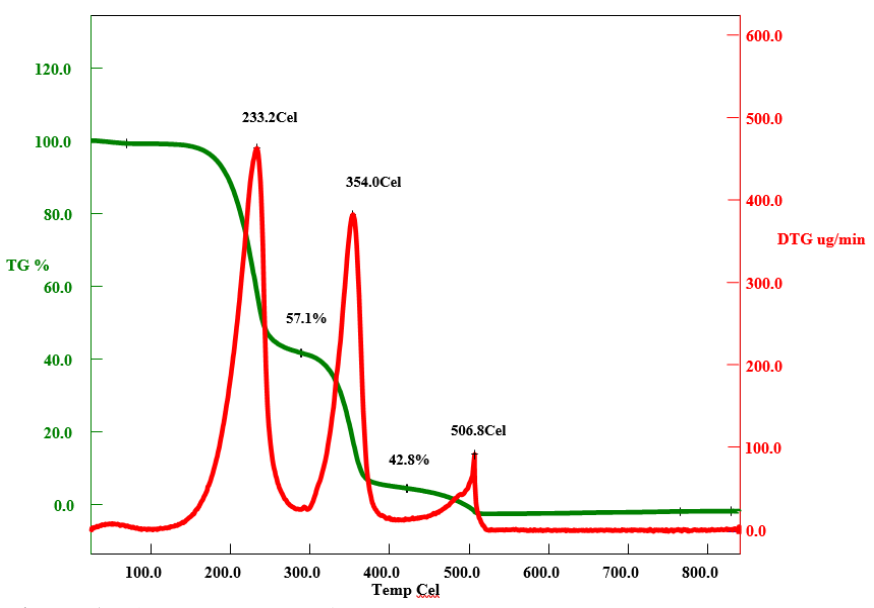

Figure 1. The TGA curves of HS-C@PIM

Thermogravimetric analysis (TGA) was performed to determine the thermal properties of new calix[4]arenebased polymer inclusion membrane (HS-C@PIM). As shown in Fig.1, almost complete thermal decomposition of HS-C@PIM was found at 130-520 oC. It was assumed that the decomposition the mercapto-substituted calix[4]arene containing dicarboxylic acid units (5) as well as thermal depolymerisation of CTA might be resulted the weight loss in a large scale.

The morphology of the polymer inclusion membrane without HS-C@PIM and calixarene was evaluated by scanning electron microscopy (SEM) (see Figure 2-a,b). When comparing both images, prominent differences over morphology associating shape and distribution for HS-C@PIM are seen (Figure 2b). This finding clearly ascribed that the mercapto-substituted calix[4]arene containing dicarboxylic acid units (5) was successfully embedded in the polymer inclusion membrane.

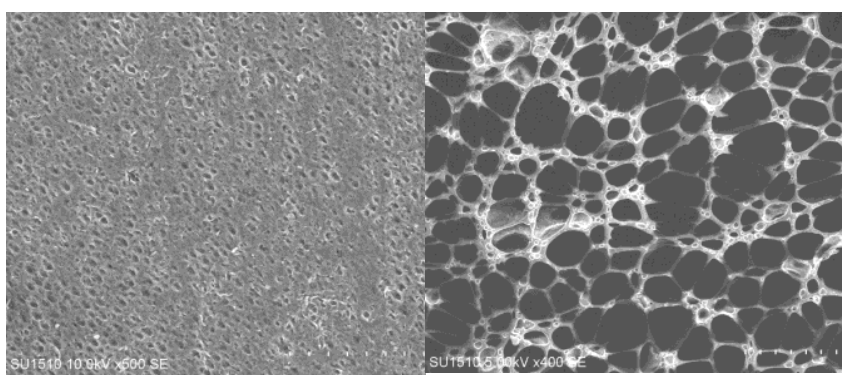

Figure 2. The SEM images (a) the polymer inclusion membrane without calixarene (b) HS-C@PIM

The amount of charged 5,17-bis-tert-butyl-11,23dicarboxylic acid-25,27-dihydroxy-26,28-bis(3-thiol-1oxypropane) calix[4]arene on HS-C@PIM was determined using elemental analysis technique. As given in Table 1, result regarding the sulfur amount of 5,17bis-tert-butyl-11,23-dicarboxylic acid-25,27-dihydroxy26,28-bis(3-thiol-1-oxypropane) calix[4]arene showed that HS-C@PIM has0.44\% sulfur content which corresponds to $0.28 \mathrm{mmol}$ of HS-C@PIM $/ \mathrm{g}$ of support (Table 1) 


\begin{tabular}{|c|c|c|c|c|c|}
\hline - & $\mathrm{C}(\%)$ & $\mathrm{H}(\%)$ & $\mathrm{S}(\%)$ & $\mathrm{N}(\%)$ & $\begin{array}{l}\text { Amount of the } \\
\text { loaded } \\
\text { calix[4]arene } \\
(\mathrm{mmol} / \mathrm{g})\end{array}$ \\
\hline Blank & 62.07 & 7.40 & - & 3.86 & - \\
\hline $\begin{array}{l}\text { HS- } \\
\text { C@PIM }\end{array}$ & 52.07 & 6.33 & 0.44 & 1.40 & $\sim 0.28$ \\
\hline
\end{tabular}

\subsection{Transport Studies}

The flux values of heavy metals were calculated by using the initial phase technique and time profile of the receiver phase concentration. The results given in Table 2 were obtained at the $95 \%$ confidence level $(\mathrm{N}=3)$. The $\mathrm{RF}$ values of the, $\mathrm{Cu}(\mathrm{II}), \mathrm{Zn}(\mathrm{II}), \mathrm{Pb}(\mathrm{II}), \mathrm{Ni}(\mathrm{II}), \mathrm{Cd}(\mathrm{II})$ and Co(II) were also shown in Table 2. It was found that the highest RF and flux values of heavy metals were obtained with $\mathrm{Cu}$ (II).

Table 2. Fluxes and values of different ions for HS-C@PIM

\begin{tabular}{lll}
\hline Ion & $\mathrm{Jx} 1015\left(\mathrm{~mol} . \mathrm{cm}^{-2} \cdot \mathrm{s}^{-1}\right)$ & $\mathrm{RF}$ \\
\hline $\mathrm{Pb}(\mathrm{II})$ & $1524.00( \pm 0.01)$ & 47.08 \\
$\mathrm{Zn}(\mathrm{II})$ & $1211.00( \pm 0.01)$ & 43.63 \\
$\mathrm{Cu}(\mathrm{II})$ & $1602.00( \pm 0.01)$ & 48.64 \\
$\mathrm{Ni}(\mathrm{II})$ & $1767.00( \pm 0.01)$ & 53.31 \\
$\mathrm{Cd}(\mathrm{II})$ & $1416.00( \pm 0.01)$ & 39.00 \\
$\mathrm{Co}(\mathrm{II})$ & $1795.00( \pm 0.01)$ & 49.42 \\
\hline
\end{tabular}

\subsection{Stability of HS-C@PIM}

Under the same experimental conditions, to assess the life of HS-C@PIM, the carrying capacity of the membrane for $\mathrm{Ni}$ (II) was examined (Feed phase: $0.1 \mathrm{~mol} / \mathrm{L} \mathrm{HCl}$ solution: Receptor phase: 10-4mol / L Ni (II)).Transport experiments were carried out using the same membrane and renewed solutions in four runs that lasted 24 hours. The transport of $\mathrm{Ni}(\mathrm{II})$ ions was observed to decrease with the number of studies and was approximately 53\% lower than the initial concentration. When the experiments lasting 2 months were completed, no structural deformation was observed in the membranes. In addition, membranes were kept in pure water after each experiment.

\section{CONCLUSION}

A synthesis of a new calixarene-based polymer inclusion membrane was introduced, and spectroscopic and other techniques were carried out to characterize it. Donnan dialysis method was applied to evaluate the metal transport efficiency of HS-C@PIM against Cu (II), Zn (II), $\mathrm{Pb}$ (II), Ni (II), Cd (II) and Co (II). The findings are given below:

1) SEM images showed that the calixarene derivative was successfully embedded in the membrane compared to the control membrane.

2) It was observed that the highest flux and RF values among heavy metals were obtained with $\mathrm{Ni}(\mathrm{II})$. In these experiments, transport was carried out using Donnan dialysis.

3) Transport experiments were carried out six times in 24-hour periods using the same membrane. The amount of Ni (II) obtained was approximately 53\% lower than the initial concentration.

4) It seems to be a feasible method with HS-C@PIM to remove six metal ions, especially $\mathrm{Ni}$ (II) from the aqueous solution by Donnan dialysis method.

\section{Acknowledgement}

In this study, for financial support we would like to thank to Turkey's Scientific and Technological Research Council (TUBITAK Grant Number 215Z570).

\section{REFERENCES}

[1] Ferguson JE. The Heavy Elements: Environment Impact and Health Effects. Pergamon Press, Oxford 1990.

[2] Khulbe KC, Matsuura T. Removal of heavy metals and pollutants by membrane adsorption techniques. Appl Water Sci 2018; 8(1).

[3] Koseoglu TS, Kir E, Ozkorucuklu SP, Karamizrak E. Preparation and characterization of P2FAn/PVDF composite cation-exchange membranes for the removal of $\mathrm{Cr}(\mathrm{III})$ and $\mathrm{Cu}(\mathrm{II})$ by Donnan dialysis. React Funct Polym 2010; 70(11): 900-7.

[4] Bonggotgetsakul YYN, Cattrall RW, Kolev SD. Recovery of gold from aqua regia digested electronic scrap using a poly (vinylidene fluorideco-hexafluoropropene) (PVDF-HFP) based polymer inclusion membrane (PIM) containing Cyphos (R) IL 104. J Membrane Sci 2016; 514: 274-81.

[5] Mahanty B, Mohapatra PK, Rant DR, Das DK, Behere PG, Afzal M, et al. Polymer Inclusion Membrane Containing a Tripodal Diglycolamide Ligand: Actinide Ion Uptake and Transport Studies. Ind Eng Chem Res 2016; 55(7): 2202-9.

[6] Kebiche-Senhadji O, Mansouri L, Tingry S, Seta P, Benamor M. Facilitated Cd(II) transport across CTA polymer inclusion membrane using anion (Aliquat 336) and cation (D2EHPA) metal carriers. J Membrane Sci 2008; 310(1-2): 438-45.

[7] Nghiem LD, Mornane P, Potter ID, Perera JM, Cattrall RW, Kolev SD. Extraction and transport of metal ions and small organic compounds using polymer inclusion membranes (PIMs). J Membrane Sci 2006; 281(1-2): 7-41.

[8] Cooper CA, Lin YS, Gonzalez M. Separation properties of surface modified silica supported liquid membranes for divalent metal removal/recovery. J Membrane Sci 2004; 229(1-2): 11-25.

[9] Bagheri M, Mashhadizadeh MH, Razee S. Solid phase extraction of gold by sorption on octadecyl silica membrane disks modified with pentathia-15crown-5 and determination by AAS. Talanta 2003; 60(4): 839-44. 
[10] Bozkurt S, Yilmaz M, Sirit A. Chiral calix[4]arenes bearing amino alcohol functionality as membrane carriers for transport of chiral amino acid methylesters and mandelic acid. Chirality 2012; 24(2): 129-36.

[11] Cay S, Sayin, S., Engin, MS. Calix[4]arene Embedded Polyamide Supported Liquid Membrane for Separation of Heavy Metals from Aqueous Solutions. Turkish Journal of Agriculture - Food Science and Technology 2020; 8(2): 387-91.

[12] Nisola GM, Cho E, Beltran AB, Han M, Kim Y, Chung WJ. Dye/water separation through supported liquid membrane extraction. Chemosphere 2010; 80(8): 894-900.

[13] Rovira M, Sastre AM. Modelling of mass transfer in facilitated supported liquid-membrane transport of palladium(II) using di-(2-ethylhexyl) thiophosphoric acid. J Membrane Sci 1998; 149(2): 241-50.

[14] Gutsche CD, Nam KC. Calixarenes .22. Synthesis, Properties, and Metal Complexation of Aminocalixarenes. J Am Chem Soc 1988; 110(18): 6153-62.

[15] Vanloon JD, Arduini A, Coppi L, Verboom W, Pochini A, Ungaro R, et al. Selective Functionalization of Calix[4]Arenes at the Upper Rim. J Org Chem 1990; 55(21): 5639-46.

[16] Demirtas HN, Bozkurt S, Durmaz M, Yilmaz M, Sirit A. Chiral calix[4]azacrowns for enantiomeric recognition of amino acid derivatives. Tetrahedron 2009; 65(15): 3014-8.

[17] Kurzatkowska K, Sayin S, Yilmaz M, Radecka H, Radecki J. Calix[4]arene derivatives as dopamine hosts in electrochemical sensors. Sensor Actuat BChem 2015; 218: 111-21.

[18] Akin S, Gulen M, Sayin S, Azak H, Yildiz HB, Sonmezoglu S. Modification of photoelectrode with thiol-functionalized Calix[4]arenes as interface energy barrier for high efficiency in dye-sensitized solar cells. J Power Sources 2016; 307: 796-805.

[19] Engin MS, Sayin S, Cay S, Kir E, SardohanKoseoglu T. Preparation and characterisation of thiol functionalised p-tert-butylcalix[4]areneembedded polymer inclusion membranes: performance and selectivity. Int $\mathrm{J}$ Environ an $\mathrm{Ch}$ 2019; 99(11): 1103-11.

[20] Arslan G, Yilmaz A, Tor A, Ersoz M. Preparation of polymer inclusion membrane with sodium diethyldithiocarbamate as a carrier reagent for selective transport of zinc ions. Desalination and Water Treatment 2017; 75: 348-356. 